\title{
Comparison of Compressive Forces on Low Back(L5/S1) for One-hand Lifting and Two-hands Lifting Activity
}

\author{
Hong-Ki Kim \\ Department of Industrial Management Engineering, Kyonggi University, Suwon, Kyonggi-do, 443-760
}

\begin{abstract}
Objective: The objective of this study was to compare one-hand and two-hands lifting activity in terms of biomechanical stress for the range of lifting heights from 10cm above floor level to knuckle height. Background: Even though two-hands lifting activity of manual materials handling tasks are prevalent at the industrial site, many manual materials handling tasks which require the worker to perform one-hand lifting are also very common at the industrial site and forestry and farming. Method: Eight male subjects were asked to perform lifting tasks using both a one-handed as well as a two-handed lifting technique. Trunk muscle electromyographic activity was recorded while the subjects performed the lifting tasks. This information was used as input to an EMG-assisted free-dynamic biomechanical model that predicted spinal loading in three dimensions. Results: It was shown that for the left-hand lifting tasks, the values of moment, lateral shear force, A-P shear force, and compressive force were increased by the average $43 \%$, as the workload was increased twice from $7.5 \mathrm{~kg}$ to $15.0 \mathrm{~kg}$. For the right-hand lifting task, these were increased by the average 34\%. For the two-hands lifting tasks, these were increased by the average $25 \%$. The lateral shear forces at L5/S1 of one-hand lifting tasks, notwithstanding the half of the workload of two-hands lifting tasks, were very high in the $300 \sim 317 \%$ of the one of two-hands lifting tasks. The moments at L5/S1 of one-hand lifting tasks were 126 166\% of the one of two-hands lifting tasks. Conclusion: It is concluded that the effect of workload for one-hand lifting is greater than two-hands lifting. It can also be concluded that asymmetrical effect of one-hand lifting is much greater than workload effect. Application: The results of this study can be used to provide guidelines of recommended safe weights for tasks involved in one-hand lifting activity.
\end{abstract}

Keywords: One-hand lifting, Moment, Lateral shear force, A-P shear force, Compressive force

\section{Introduction}

산업 현장에서 작업자의 근골격계에 심한 부담을 주는 작 업들은 그 작업 부하가 작업자의 근골격계 능력(해당 근육 에서의 최대 근력, 최대 허용 하중 등)에 상당하거나 또는 능가하는 경우라고 할 수 있다. 이러한 경우 작업자는 근골 격계 질환을 유발하게 되는 높은 위험 부담에 놓이게 된다. 근골격계 질환의 대표적인 질환으로서 요통 $(\mathrm{LBP}, \mathrm{Low}$ Back Pain)을 꼽을 수 있는데 요추 부위에 가장 많은 스트레스를
주는 대표적인 작업으로서 인력물자취급 작업의 하나인 들 기 작업을 들 수 있다.

지금까지 인력운반취급 작업에 관한 연구로서 들기 작 업은 학자들의 많은 관심의 대상이었으며 특히 생체역학적 관점에서의 들기 작업의 기준 항목으로서 들기 작업에 관 련되는 근육에 대한 근력과 요추 부위에 미치는 부하로서 작업 하중, 작업 빈도수 내지는 누적 작업 빈도수, 압축 력(Compressive force), 전단력(Shear force), 모멘트 (Moment) 등이 관심의 대상이었다. 특히 요추 부위 (L5/ $\mathrm{S} 1)$ 의 압축력은 지난 반세기에 걸쳐 많은 관심을 끌어왔다.

Corresponding Author: Hong-Ki Kim. Department of Industrial Management Engineering, Kyonggi University, Suwon, Kyonggi-do, 443-760. Phone: 031-249-9752, E-mail: hkkim@kyonggi.ac.kr

Copyright@2011 by Ergonomics Society of Korea(pISSN:1229-1684 eISSN:2093-8462). All right reserved. 


\subsection{Background and objective}

산업 현장에서의 들기 작업은 양손에 의한 들기 작업뿐 만 아니라 한 손에 의한 들기 작업이 빈번하게 이루어지고 있 는 실정이다. 작업자들은 가끔 제한된 또는 열악하게 설계된 작업 공간 내에서 한 손에만 의한 작업을 수행하여야 할 경 우가 있다(Marras and Davis, 1998). 최근 국내 기업들이 근골격계 유해요인 조사를 실시할 때 한 손 동작이 빈번히 발생하는 작업의 부하를 정량적으로 판단하고자 할 때 어려 움을 겪는 요인이 되고 있다(Mo et al., 2010). 그러므로 한 손만을 사용한 비대칭적인 들기 작업은 신체 활동의 비 대칭성을 유발하며 이에 따른 근골격계 질환 가능성은 간과 되어서는 안 될 것이다.

그러나 지금까지의 대부분의 들기 작업 관련 연구는 양 손을 사용한 들기 작업이며 한 손만을 사용한 들기 작업에 관한 연구는 별로 많이 수행되어 오지 않았다(Garg and Saxena, 1982; Garg, 1983; Mital and Ilango, 1983; Allread et al., 1996; Marras and Davies, 1998; Mital and Kumar, 1998a,b, Gall and Parkhouse, 2004).

본 연구의 목적은 두 가지 중량 $7.5 \mathrm{~kg}, 15.0 \mathrm{~kg}$ 에 대하여 왼손 또는 오른손만을 사용하거나 양손을 사용하는 경우에 대하여 생체역학적 관점에서의 요추 부위의 모멘트, 전단응 력, 압축력에 대한 영향을 분석하고 비교하고자 하였다. 또 한 들기 작업에 대한 최대 근력 측정의 결과와도 비교해 보 고자 하였다.

\section{Design of Experiments and Experimental Procedures}

8명의 피실험자에 대하여 두 가지 작업 형태(한 손 들기 작업, 양손 들기 작업), 두 가지 작업 하중 $(7.5 \mathrm{~kg}, 15 \mathrm{~kg})$ 의 $2 \times 2$ 요인 난괴법 (factorial randomized complete block design)을 반복 2 회 적용하였다. 이 때 피실험자 군을 블록 으로 사용하였다. 본 연구를 위한 실험계획 모델은 다음과 같다.

$Y_{i j k l}=\mu+S_{i}+H_{j}+L_{k}+(S H)_{i j}+(S L)_{i k}+(H L)_{j k}$ $+(S H L)_{i j k}+\epsilon_{i j k l}$

$Y_{i j k l}=$ Moment, Lateral shear force, A-P shear force, Compressive force,

$\mu=$ Moment, Lateral shear force, $\mathrm{A}-\mathrm{P}$ shear force, Compressive force 들의 모평균,

$S_{i}=$ Subject $\mathrm{i} \quad \mathrm{i}=1,2, \cdots, 8$,

$$
\begin{array}{lll}
H_{j} & =\text { Hand } \mathrm{j} & \mathrm{j}=1,2,3 . \\
L_{k} & =\text { Load } \mathrm{k} & \mathrm{k}=1,2, \\
l & =\text { Repetition } & \mathrm{l}=1,2, \\
\epsilon_{i j k l}=\text { Error term } & \sim N\left(0, \sigma^{2}\right) .
\end{array}
$$

본 실험에서는 들기 작업의 작업 빈도는 실험 인자로서 채택하지 않았다.

\subsection{Subjects}

본 실험에 참여한 인원은 8명으로서 20 29세 사이의 대 학생 또는 대학원생 이었다. 현재 요통이 있거나 과거에 요 통 경력이 있는 대학생은 제외하였다. 8명 모두 다 오른손 잡이였다. 피실험자들의 인체측정 결과는 표 1 과 같다.

Table 1. Anthropometry of the subjects

\begin{tabular}{c|c|c|c|c}
\hline & $\begin{array}{c}\text { Age } \\
(\text { Years })\end{array}$ & $\begin{array}{c}\text { Body Weight } \\
(\mathrm{kg})\end{array}$ & $\begin{array}{c}\text { Stature } \\
(\mathrm{cm})\end{array}$ & $\begin{array}{c}\text { Knuckle Height } \\
(\mathrm{cm})\end{array}$ \\
\hline Mean & 23.9 & 79.37 & 179.84 & 79.18 \\
\hline SD & 2.7 & 19.54 & 6.82 & 3.01 \\
\hline
\end{tabular}

\subsection{Equipments used for experiments}

본 실험을 위하여 미국의 Ohio State University의 Biodynamics Lab에서 개발한 EMG 보조 자유 동적 생체 역학 모델(EMG-assisted Free-dynamic Biomechanical Model)을 이용하였다. 이 모델을 이용하기 위해서는 관련 되는 총 10 개의 근육 활동에 대한 $\mathrm{EMG}$ 데이터가 필요하 고, 몸통의 위치와 속도를 추적하기 위한 Lumbar Motion Monitor (LMM) 가 사용되었다. 또한 $\mathrm{EMG}$ 보조 자유 동적 생체역학 모델을 사용하는데 필수적인 항목들에 대한 입 력과 각 종 아날로그 신호를 디지털 신호로 전환시키는 데 이터 획득 하드웨어 (data acquisition hardware, NIDAQ) 를 조절하고 수집된 데이터를 분석하기 위해서 Laboratory Information Management System(LIMS, version 1.24) 이 사용되었다.

\subsubsection{Lumbar Motion Monitor(LMM)}

허리 몸통(Lumbar Trunk)의 3차원 동작 분석을 위하여 일종의 3축 고니오미터(tri-axial goniometer)에 해당하는 Lumbar Motion Monitor (LMM) 가 사용되었다. 이 장치의 재원과 정확도는 이미 학계에 보고되어 있다(Marras et al., 1990; Marras et al., 1992). 본 실험에서 사용된 gain 값은 8명의 피실험자가 각 각 다르지만 그 범위는 24 126N/ 
$\mathrm{cm}^{2}$ 이었다.

\subsubsection{Electromyography}

들기 내리기 작업과 관련된 근육 활동 data를 수집하기 위해서 $\mathrm{EMG}$ 를 사용하였다. 관련 근육들은 요부 척주기립 근(Erector Spinae), 광배근(Latissimus Dorsi), 외복사근 (External Oblique), 내복사근(Internal Oblique), 복직근 (Rectus Abdominis)으로서 좌 우 각 5 개, 총 10 개의 허리 관련 근육들이다.

이들 근육들에 양극 표면 전극(bipolar surface electrodes)을 $3 \mathrm{~cm}$ 간격으로 부착하였다. 이들의 정확한 위치 는 관련 참고문헌(Mirka and Marras, 1993)에 따랐다.

각 근육들의 왼쪽, 오른쪽에 양극 표면 전극들을 부착한 다음 저항을 측정하여 왼쪽과 오른쪽 표면 전극의 저항 차이 가 $50 \%$ 이내가 되지 않거나 각 각의 저항이 $500 \mathrm{ohm}$ 이상 이 되면 표면 전극을 다시 부착하도록 하였다. 데이터 샘플 링 빈도는 원래의 $\mathrm{EMG}$ 신호에 적합한 $1,000 \mathrm{~Hz}$ 로 하였다.

\subsubsection{Laboratory Information Management System (LIMS)}

이 소프트웨어는 데이터 샘플링을 위한 아날로그-디지털 변환기(Analog-Digital Converting board)인 NI-DA2821 (National Instruments Corporation)을 다루기 쉽게 만들 었으며 또한 $\mathrm{EMG}$ 보조 자유 동적 생체역학 모델을 실행시 키고 그 결과를 상세히 보여 줄 수 있는 프로그램이다(LIMS version 1.24, AMT System, Columbus, Ohio, USA).

\subsubsection{Force plate}

반발력 (Ground reaction force)을 측정하기 위하여 Bertec 4060A force plate(Bertec Corporation, Columbus, Ohio, U.S.A.) 가 사용되었다.

\subsubsection{Lifting box}

작업 상자의 크기는 $40.6 \times 20.3 \times 20.3 \mathrm{~cm}\left(16^{\prime \prime} \times 8 " \times 8 "\right)$ 이었다. 상단부 중앙에 파이프를 설치하여 한 손 작업의 경 우 손잡이로 사용하였다. 좌 우 양면에는 양손 작업을 위한 손잡이 용도로 $2.5 \mathrm{~cm}$ 높이와 $12.7 \mathrm{~cm}$ 길이의 구멍을 내었 다. 내부에 균형이 잡히도록 철근을 넣어 무게 $7.5 \mathrm{~kg}$ 과 15 $\mathrm{kg}$ 의 두 종류 작업 상자를 만들어 사용하였다.

\subsection{Experimental procedures}

피실험자는 요부 몸통 관련 10 개의 근육에 $\mathrm{EMG}$ 피부 표면 전극들을 부착한 다음 실험 시작 전 까지 약 30분간 의 휴식과 안정을 취하도록 하였다. LMM을 착용하고 PSS
(Pelvic Support System)에 찍찍이(Velcro)를 이용하여 허리 부위를 고정시키고 $\mathrm{ARF}$ (Asymmetric Reference Frame)에 어깨높이의 상체 부위를 고정시켰다. 이 위치에 서 네 가지 종류의 허리 몸통 근력 발휘(trunk exertion), 즉 굴전(flexion), 신전(extension) 과 오른쪽 비틀기 (right (clockwise) twist), 왼쪽 비틀기(left (counter clockwise) twist)를 실시하여 MVC(Maximum Voluntary Contraction) 들을 측정하였다. 이 $\mathrm{MVC}$ 는 허리 몸통 관련 근육들에 대한 정규화(normalization)에 사용되었다. 이들 기초 실험이 끝 나면 의도했던 실험계획법에 따라 독립 변수들의 조합에 따 른 실제 실험을 수행하였다.

$7.5 \mathrm{~kg}$ 과 $15 \mathrm{~kg}$ 의 작업 상자(손잡이 높이는 상자 바닥으로 부터 $10 \mathrm{~cm}$ 높이)를 바닥으로 부터 피실험자들의 손가락 관절높이 까지 왼손과 오른손 한 쪽만을 이용하는 한 손 들 기 작업 그리고 양손을 동시에 이용하는 들기 작업을 각 각 2 회 무작위로 실행하였다. 실행 간의 휴식 시간은 10 분이 었다.

이들 작업에 따른 실험 결과는 LIMS의 데이터 수집단계 에 기록되어졌다.

\section{Results and Analysis}

모든 실험을 끝내고 $\mathrm{LIMS}$ 를 사용하여 분석된 결과들에 대한 자료들을 정리한 결과는 다음과 같다.

\subsection{Analysis of variance}

8명의 피실험자에 대하여 왼손, 오른손, 양손 들기 작업, 두 가지 작업 하중 $(7.5 \mathrm{~kg}, 15 \mathrm{~kg})$ 의 $3 \times 2$ 요인 난괴법 디자 인을 반복 2회 적용한 실험 결과에 따른 모멘트와 좌-우측 전단력 (lateral shear force), 전-후방 전단력 (A-P shear force) 및 압축력(compressive force)들에 대하여 ANOVA 분석을 한 결과, 유의수준 0.05 에서 모멘트, 좌-우측 전단 력, 전-후방 전단력, 압축력들 모두 사용하는 손에 따른 유 의한 차이가 없었다. 그러나 작업 하중에 따라서는 유의수준 0.05 에서 유의한 차이를 나타내었다. 사용하는 손과 작업 하중간의 교호작용은 유의수준 0.05 에서 유의한 차이가 없 었다. ANOVA 분석 결과 유의확률은 표 2에 정리하였다.

모멘트, 좌-우측 전단력, 전-후방 전단력, 압축력들 모두 사용하는 손에 따른 통계적으로 유의한 차이가 없었으나 왼 손과 양손 작업만을 비교해 보면 모멘트의 경우 유의확률 은 0.0310, 좌-우 전단력의 경우 0.0006으로 유의한 차 이가 있었다. 그러나 전-후방 전단력과 압축력은 유의수준 
0.05에서 유의한 차이가 없었다. 오른손과 양손 작업만을 비 교해 보면 4가지 항목 모두 다 유의수준 0.05 에서 사용하는 손에 따른 유의한 차이가 없었다. 또한 왼손과 오른손 작업 의 경우도 마찬가지로 유의수준 0.05 에서 모두 유의한 차이 가 없었다.

Table 2. Results of ANOVA for moment, lateral shear force, A-P shear force, and compressive force at L5/S1

\begin{tabular}{c|r|r|r|r|r}
\hline \multirow{2}{*}{ Source } & \multirow{2}{*}{$\mathrm{DF}$} & \multicolumn{4}{|c}{ Pr $>\mathrm{F}$} \\
\cline { 3 - 6 } & & $\begin{array}{c}\text { Moment } \\
(\mathrm{Nm})\end{array}$ & $\begin{array}{c}\text { Lateral } \\
\text { shear } \\
\text { force }(\mathrm{N})\end{array}$ & $\begin{array}{c}\text { A-P } \\
\text { shear } \\
\text { force }(\mathrm{N})\end{array}$ & $\begin{array}{c}\text { Compressive } \\
\text { force }(\mathrm{N})\end{array}$ \\
\hline $\mathrm{S}$ & 7 & $<0.0001$ & $<0.0001$ & $<0.0001$ & $<0.0001$ \\
\hline $\mathrm{H}$ & 2 & 0.0653 & 0.1003 & 0.4342 & 0.3075 \\
\hline $\mathrm{S} * \mathrm{H}$ & 14 & $<0.0001$ & $<0.0001$ & $<0.0001$ & $<0.0001$ \\
\hline $\mathrm{L}$ & 1 & 0.0081 & 0.0033 & 0.0146 & 0.0023 \\
\hline $\mathrm{S} * \mathrm{~L}$ & 7 & 0.0013 & 0.5108 & $<0.0001$ & 0.0019 \\
\hline $\mathrm{H} * \mathrm{~L}$ & 2 & 0.1422 & 0.0624 & 0.2057 & 0.1440 \\
\hline $\mathrm{S} \mathrm{H}^{*} \mathrm{~L}$ & 14 & 0.0420 & 0.7596 & 0.0005 & 0.0471 \\
\hline Error & 47 & & & & \\
\hline Total & 94 & & & & \\
\hline
\end{tabular}

$\mathrm{S}=$ Subjects $(8$ persons $)$

$\mathrm{H}=$ Hands used(Left hand, Right hand, Two hands)

$\mathrm{L}=$ Work load $(7.5 \mathrm{~kg}, 15.0 \mathrm{~kg})$

\subsection{Analysis of moment, lateral shear force, A-P shear force, and compressive force for lifting task}

$7.5 \mathrm{~kg}$ 과 $15 \mathrm{~kg}$ 의 중량물을 바닥에서 $10 \mathrm{~cm}$ 높이로 부터 피실험자들의 손가락 관절높이(knuckle height)까지 들기 작업에 따른 $\mathrm{L} 5 / \mathrm{S} 1$ 에서의 모멘트와 좌-우측 전단력, 전후방 전단력 및 압축력에 대한 결과는 표 3 과 같다.

작업 하중 $7.5 \mathrm{~kg}$ 을 왼손으로 드는 작업의 경우 $\mathrm{L} 5 / \mathrm{S} 1$ 에 서의 모멘트, 좌-우측 전단력, 전-후방 전단력 및 압축력은 양손의 경우에 비하여 높은 것으로 나타났다. 오른손의 경우 는 전-후방 전단력은 양손의 경우와 거의 같았으나 모멘트, 좌-우측 전단력, 압축력은 양손의 경우에 비하여 높게 나타 났다. 한 손 작업의 경우 모멘트는 양손의 경우 보다 159 $209 \%$ 높은 것으로 나타났다. 또한 압축력의 경우는 120 $129 \%$ 높았고 $6,000 \mathrm{~N}$ 이상이었다. 특히 괄목할 사항은 좌 -우측 전단력의 경우 393 416\% 정도로 무척 큰 차이가 났으며 그 수치도 $1,200 \mathrm{~N}$ 을 능가했다. 전-후방 전단력은 모든 경우 $3,000 \mathrm{~N}$ 이상이었다. 왼손과 오른손을 비교해 보 면 왼손의 경우 모멘트는 오른손 경우의 $76 \%$ 였으나 전-후 방 전단력은 $124 \%$ 였다. 그러나 좌-우측 전단력 및 압축력 은 각 각 $95 \%, 93 \%$ 였다.
Table 3. Moment, lateral shear force, A-P shear force, and compressive force at L5/S1 by hand used and work load(Mean(SD))

\begin{tabular}{|c|c|c|c|c|c|}
\hline $\begin{array}{l}\text { Hands } \\
\text { Used }\end{array}$ & $\begin{array}{l}\text { Work } \\
\text { Load } \\
(\mathrm{kg})\end{array}$ & $\begin{array}{l}\text { Moment } \\
(\mathrm{Nm})\end{array}$ & $\begin{array}{l}\text { Lateral } \\
\text { Shear force } \\
\text { (N) }\end{array}$ & $\begin{array}{c}\text { A-P } \\
\text { Shear force } \\
\text { (N) }\end{array}$ & $\begin{array}{l}\text { Compressive } \\
\text { force } \\
\text { (N) }\end{array}$ \\
\hline \multirow{2}{*}{$\begin{array}{l}\text { Left } \\
\text { Hand }\end{array}$} & 7.5 & $\begin{array}{c}420.1 \\
(219.2)\end{array}$ & $\begin{array}{l}1266.2 \\
(847.8)\end{array}$ & $\begin{array}{c}3915.2 \\
(3677.5)\end{array}$ & $\begin{array}{c}6489.6 \\
(3050.6)\end{array}$ \\
\hline & 15.0 & $\begin{array}{c}621.1 \\
(340.2)\end{array}$ & $\begin{array}{l}1727.5 \\
(713.2)\end{array}$ & $\begin{array}{c}5695.0 \\
(5398.2)\end{array}$ & $\begin{array}{c}9154.8 \\
(3777.1)\end{array}$ \\
\hline \multirow{2}{*}{$\begin{array}{l}\text { Two } \\
\text { Hands }\end{array}$} & 7.5 & $\begin{array}{c}264.7 \\
(136.5)\end{array}$ & $\begin{array}{c}322.3 \\
(286.9)\end{array}$ & $\begin{array}{c}3194.4 \\
(1348.5)\end{array}$ & $\begin{array}{c}5405.4 \\
(1931.9)\end{array}$ \\
\hline & 15.0 & $\begin{array}{c}333.3 \\
(189.6) \\
\end{array}$ & $\begin{array}{c}422.7 \\
(378.7) \\
\end{array}$ & $\begin{array}{c}3815.6 \\
(1424.4) \\
\end{array}$ & $\begin{array}{c}6619.7 \\
(2483.1) \\
\end{array}$ \\
\hline \multirow{2}{*}{$\begin{array}{l}\text { Right } \\
\text { Hand }\end{array}$} & 7.5 & $\begin{array}{c}552.6 \\
(429.3) \\
\end{array}$ & $\begin{array}{c}1339.7 \\
(1583.4) \\
\end{array}$ & $\begin{array}{c}3146.8 \\
(3253.1) \\
\end{array}$ & $\begin{array}{c}6981.2 \\
(4554.6) \\
\end{array}$ \\
\hline & 15.0 & $\begin{array}{c}739.5 \\
(504.0)\end{array}$ & $\begin{array}{c}1673.5 \\
(1954.0)\end{array}$ & $\begin{array}{c}4486.5 \\
(3894.8)\end{array}$ & $\begin{array}{c}9377.2 \\
(5276.4)\end{array}$ \\
\hline
\end{tabular}

작업 하중 $15 \mathrm{~kg}$ 의 경우는 $\mathrm{L} 5 / \mathrm{S} 1$ 에서의 모멘트, 좌-우측 전단력, 전-후방 전단력 및 압축력은 왼손, 오른손 모두 양 손의 경우에 비하여 높은 것으로 나타났다. 한 손 작업의 경 우 모멘트는 양손의 경우 보다 186 222\% 높은 것으로 나 타났다. 또한 압축력의 경우는 138 142\%로 높았으며 모두 $9,000 \mathrm{~N}$ 이상이었다. 특히 괄목할 사항은 좌-우측 전단력 의 경우 396 409\% 정도로 큰 차이가 났으며 그 수치도 $1,600 \mathrm{~N}$ 이상이었다. 전-후방 전단력은 모든 경우 $4,000 \mathrm{~N}$ 을 능가하는 높은 값을 나타내었다. 왼손과 오른손을 비교해 보면 왼손의 경우 모멘트는 오른손 경우의 $84 \%$ 였으나 전후방 전단력은 $127 \%$ 였다. 그러나 좌-우측 전단력 및 압축 력은 각 각 $103 \%, 98 \%$ 였다.

\subsection{Analysis of moment, lateral shear force, A-P shear} force, and compressive force when maximum static muscle exertion

왼손, 오른손, 양손을 사용하여 손가락 관절높이에서의 정 적 최대 근력 발휘에 따른 $\mathrm{L} 5 / \mathrm{S} 1$ 에서의 모멘트, 좌-우측 전단력, 전-후방 전단력, 및 압축력들은 표 4 와 같다. 왼손 과 오른손의 정적 최대 근력은 유의수준 0.05 에서 유의한 차이가 없었다. 또한 정적 최대 근력 발휘 시의 왼손과 오른 손의 모멘트, 좌-우측 전단력, 전-후방 전단력, 압축력 모 두 다 유의수준 0.05 에서 유의한 차이가 없었다.

왼손과 오른손의 손가락 관절높이에서의 정적 최대 근력은 양손의 최대 근력의 $62 \%$ 와 $65 \%$ 에 불과하였으나 모멘트는 $167 \%, 208 \%$ 였으며 좌-우측 전단력은 $227 \%, 248 \%$, 전후방 전단력은 $184 \%, 236 \%$, 압축력은 $107 \%, 122 \%$ 였다. 
Table 4. Moment, lateral shear force, A-P shear force, and compressive force at L5/S1 with maximum static muscle exertion by hand used(Mean(SD))

\begin{tabular}{c|c|c|c|c|c}
\hline $\begin{array}{c}\text { Hand } \\
\text { Used }\end{array}$ & $\begin{array}{c}\text { IPF } \\
\text { Knuckle } \\
\text { Height } \\
(\mathrm{N})\end{array}$ & $\begin{array}{c}\text { Moment } \\
(\mathrm{Nm})\end{array}$ & $\begin{array}{c}\text { Lateral } \\
\text { Shear force } \\
(\mathrm{N})\end{array}$ & $\begin{array}{c}\text { A-P } \\
\text { shear force } \\
(\mathrm{N})\end{array}$ & $\begin{array}{c}\text { Compressive } \\
\text { Force } \\
(\mathrm{N})\end{array}$ \\
\hline $\begin{array}{c}\text { Left } \\
\text { Hand }\end{array}$ & $\begin{array}{c}501.2 \\
(131.2)\end{array}$ & $\begin{array}{c}199.1 \\
(109.9)\end{array}$ & $\begin{array}{c}213.4 \\
(154.2)\end{array}$ & $\begin{array}{c}610.1 \\
(394.0)\end{array}$ & $\begin{array}{c}2431.5 \\
(1145.1)\end{array}$ \\
\hline Two & 808.2 & 119.6 & 93.9 & 332.0 & 2263.3 \\
Hands & $(399.9)$ & $(79.8)$ & $(66.4)$ & $(279.0)$ & $(1611.4)$ \\
\hline Right & 522.0 & 248.5 & 232.6 & 782.8 & $\begin{array}{c}2749.7 \\
\text { Hand }\end{array}$ \\
$(130.6)$ & $(218.0)$ & $(158.6)$ & $(684.1)$ & $(2154.9)$ \\
\hline
\end{tabular}

$\mathrm{IPF}=$ Isometric Peak Force(N)

손가락 관절높이에서의 왼손과 오른손의 정적 최대 근력 발휘 시의 모멘트, 좌-우측 전단력, 전-후방 전단력, 압축 력 모두 다 작업 하중이 $7.5 \mathrm{~kg}, 15.0 \mathrm{~kg}$ 의 경우 보다 모두 낮게 나타났다.

\section{Discussion}

\subsection{Effect of work load}

$\mathrm{L} 5 / \mathrm{S} 1$ 에서의 모멘트는 작업 하중이 2배로 증가함에 따 라 왼손의 경우 $148 \%$, 오른손의 경우는 $134 \%$, 양손의 경 우는 $126 \%$ 였다. 좌-우측 전단력은 작업 하중이 2 배로 증 가함에 따라 왼손의 경우 $136 \%$, 오른손의 경우는 $125 \%$, 양손의 경우는 $131 \%$ 였다. 작업 하중이 2 배로 증가함에 따 라 전-후방 전단력은 왼손의 경우 $146 \%$, 오른손의 경우는 $143 \%$, 양손의 경우는 $119 \%$ 였다. 압축력의 경우는 왼손의 경우 $141 \%$, 오른손의 경우는 $134 \%$, 양손의 경우는 $123 \%$ 였다.

작업 하중 $15 \mathrm{~kg}$ 과 $7.5 \mathrm{~kg}$ 에 따른 영향을 종합적으로 살 펴보면 왼손의 경우 작업 하중이 2 배로 증가함에 따라 모멘 트, 좌-우측 전단력, 전-후방 전단력 및 압축력 들은 평균 $143 \%$, 오른손의 경우는 $134 \%$, 양손의 경우는 $125 \%$ 였다. 그러므로 작업 하중의 영향은 양손 들기 작업 보다는 한 손 들기 작업의 경우에 더 큰 영향을 준다고 할 수 있다.

작업 하중 $7.5 \mathrm{~kg}, 15.0 \mathrm{~kg}$ 에 대하여 한 손 들기 작업의 경 우는 양손 작업의 경우보다 L5/S1에서의 모멘트는 159 $209 \%$, 좌-우측 전단력은 393 416\%, 전-후방 전단력은 99 123\%, 압축력은 120 129\% 높았는데 이러한 결과로 미루어 본다면 한 손 들기 작업의 생체역학적 작업 부하는 양손 들기 작업의 생체역학적 작업 부하보다 훨씬 높다고 할 수 있을 것이다. 특히 좌-우측 전단력이 4 배로 나타난
것은 한 손 들기 작업의 좌-우측 비대칭성에 따른 심각한 영향을 보여주는 것이라 생각한다.

\subsection{Comparison of one-hand and two-hands lifting tasks}

작업 하중 $7.5 \mathrm{~kg}$ 을 왼손으로 드는 경우를 작업 하중 15.0 $\mathrm{kg}$ 을 양손으로 드는 경우와 비교해 보면, L5/S1에서의 전 -후방 전단력과 압축력은 큰 차이가 없었으나 모멘트는 $126 \%$, 좌-우측 전단력은 $300 \%$ 였다. 또한 작업 하중 7.5 $\mathrm{kg}$ 을 오른손으로 드는 경우를 작업 하중 $15.0 \mathrm{~kg}$ 을 양손으 로 드는 경우와 비교해 보면, $\mathrm{L} 5 / \mathrm{S} 1$ 에서의 전-후방 전단 력은 $83 \%$ 정도였고, 압축력은 $106 \%$ 였던 반면, 모멘트는 $166 \%$, 좌-우측 전단력은 $317 \%$ 였다.

한 손 작업의 작업 하중이 양손 작업의 작업 하중의 절반 이었음에도 불구하고 L5/S1에서의 모멘트는 126 166\%, 좌-우측 전단력은 300 317\%로 매우 높았다. 이는 한 손 작업의 경우 작업 하중의 영향 보다는 비대칭성의 영향이 훨씬 크다는 사실을 입증한다고 할 수 있다.

\subsection{Comparison of left-hand and right-hand lifting tasks}

작업 하중 $7.5 \mathrm{~kg}$ 에 대하여 왼손과 오른손을 비교해 보면 왼손의 경우 모멘트는 오른손 경우의 $76 \%$ 였으나 전-후방 전단력은 $124 \%$ 였다. 그러나 좌-우측 전단력 및 압축력은 큰 차이가 없었다.

작업 하중 $15.0 \mathrm{~kg}$ 에 대하여 왼손과 오른손을 비교해 보면 왼손의 경우 모멘트는 오른손 경우의 $84 \%$ 였으나 전-후방 전단력은 $127 \%$ 였다. 그러나 좌-우측 전단력 및 압축력은 큰 차이가 없었다고 할 수 있다. 이러한 경향은 $7.5 \mathrm{~kg}$ 의 경 우와 같다고 할 수 있겠다.

작업 하중에 관계없이 왼손의 경우 모멘트는 오른손의 약 $80 \%$, 전-후방 전단력은 약 $125 \%$ 라 할 수 있다. 그러나 좌 -우측 전단력 및 압축력은 큰 차이가 없다고 할 수 있다.

\subsection{Comparison of compressive forces with one-hand lifting tasks and NIOSH AL or RWL}

본 연구의 작업조건에 해당하는 NIOSH의 Guideline의 기준치 AL(Action Limit)은 $14.2 \mathrm{~kg}$, RWL(Recommended Weight of Lift)은 $11.7 \mathrm{~kg}$ 이다(NIOSH, 1981; Waters et al., 1993). 본 연구의 한 손 들기에 대한 작업 하중 $7.5 \mathrm{~kg}$ 은 $\mathrm{NIOSH}$ 의 양손 들기에 대한 $\mathrm{AL}$ 해당 작업 하중 $14.2 \mathrm{~kg}$ 의 절반인 $7.1 \mathrm{~kg}$ 보다 약간 높지만 비교 차원에서 고려해 보 았다. 작업 하중 $7.5 \mathrm{~kg}$ 에 대한 왼손 들기 작업의 압축력은 $6,490 \mathrm{~N}$, 오른손 들기 작업의 압축력은 $6,981 \mathrm{~N}$ 으로서 이 
수치들은 NIOSH의 AL에 해당하는 압축력의 기준치 3,430 $\mathrm{N}$ 의 각 각 $189 \%, 204 \%$ 에 해당하였다. 좌-우측 전단력은 McGil(McGil, 1996)이 주장한 한계치(tolerance) 1,000N 의 각 각 $127 \%, 134 \%$ 에 해당하였다. 전-후방 전단력은 이 $1,000 \mathrm{~N}$ 의 각 각 $392 \%, 315 \%$ 로서 상당히 높은 결과를 나 타내고 있다.

\section{Conclusion and Recommendations}

작업 하중 $15 \mathrm{~kg}$ 과 $7.5 \mathrm{~kg}$ 에 따른 영향을 살펴보면 왼손의 경우 작업 하중이 2 배로 증가함에 따라 모멘트, 좌-우측 전 단력, 전-후방 전단력 및 압축력들은 평균 $143 \%$, 오른손의 경우는 $134 \%$, 양손의 경우는 $125 \%$ 였다. 그러므로 작업 하 중의 영향은 양손 보다는 한 손의 경우가 더 크다고 할 수 있다.

작업 하중에 따라 약간의 차이는 있으나 왼손의 경우 모멘 트는 오른손의 약 $80 \%$, 전-후방 전단력은 약 $125 \%$ 라 할 수 있다. 그러나 좌-우측 전단력 및 압축력은 큰 차이가 없다고 할 수 있다.

한 손 작업의 작업 하중이 양손 작업의 작업 하중의 절반 이었음에도 L5/S1에서의 모멘트는 126 166\%, 좌-우측 전단력은 300 317\%로 매우 높았다. 이는 한 손 작업의 경 우 작업 하중의 영향보다는 비대칭성의 영향이 훨씬 크다고 할 수 있다.

이러한 결과들로 미루어 볼 때 한 손 들기 작업은 양손 들기 작업보다 요추 부위에 미치는 생체역학적 작업 부하가 훨씬 크다고 할 수 있다. 그러므로 양손 들기 작업에 적용하 는 NIOSH의 Guideline의 기준치들을 한 손 들기 작업에 적용하기에는 적절하지 못 하므로 한 손 들기 작업에 대한 새로운 지침을 만들기 위한 연구가 필요하다고 생각한다.

손가락 관절높이에서의 왼손과 오른손의 정적 최대 근력 발휘 시의 모멘트, 좌-우측 전단력, 전-후방 전단력, 압축 력 모두 다 작업 하중이 $7.5 \mathrm{~kg}, 15.0 \mathrm{~kg}$ 의 경우 보다 모두 낮게 나타난 결과로 미루어 볼 때 과연 정적 최대 근력 측 정 결과를 한 손 작업의 안전 하중을 예측하기 위한 지표로 사용할 수 있는가에 대한 의문을 제기하게 된다.

바닥으로부터 들기 작업 시 요추 부위에 최대 압축력이 발생하는 시점은 바닥에서 물체가 움직이기 시작하여 200 $\mathrm{msec}$ 이내로 알려져 있다(Freivalds et al., 1984). 그러나 일반적으로 정적 최대 근력 측정은 바닥에서 $38 \mathrm{~cm}$ 높이에 서 측정해 왔다. 또한 정적 최대 근력은 근력 발휘 시의 손의 높이에 따라 영향을 받는다고 알려져 있다. 본 연구에 서는 바닥에서의 정적 최대 근력 측정을 하지 않았고 이 전
의 손가락 관절높이에서의 정적 최대 근력의 연구 자료를 이 용하였다. 그러므로 추 후 들기 작업의 시점인 바닥에서의 정적 최대 근력 측정을 한 결과와 비교하는 연구가 요구된다. 본 연구는 남성 피실험자만을 고려하였으므로 과연 이 실 험 결과가 여성 피실험자에 대해서도 유사한 결과를 보여 줄 지는 확신할 수 없으므로, 추 후 여성 피실험자를 대상으로 한 유사한 연구가 수행되었으면 한다.

\section{Acknowledgements}

This study was supported by the grants from Kyonggi University Research Fund in 2009.

\section{References}

Allread, W. G., Marras, W. S. and Parnianpour, M., Trunk kinematics of one-handed lifting, and the effects of asymmetry and load weight, Ergonomics, 39(2), 322-334, 1996.

Bertec Force Plate 4060A, Bertec Corporation, 6171 Huntley Road, Suite 3, Columbus, Ohio, U.S.A.

Freivalds, A., Chaffin, D. B., Garg, A. and Lee, K. S., A Dynamic Biomechanical Evaluation of Lifting Maximum Acceptable Loads, Journal of Biomechanics, 17(4), 251-262, 1984.

Gall, B. and Parkhouse, W., Changes in physical capacity as a function of age in heavy manual work, Ergonomics, 47(6), 671-687, 2004.

Garg, A., Physiological response to one-handed in the horizontal plane by female workers, American Industrial Hygiene Association Journal, 44, 190-200, 1983

Garg, A. and Saxena, U., Maximum frequency acceptable to female workers for one-handed lifts in the horizontal plane, Ergonomics, 25(9), 839 $-853,1982$.

Laboratory Information Management System, LIMS Version 1.24, AMT System, Columbus, Ohio, U.S.A.

Marras, W. S., Davis, S. W., Miller, R. J. and Mirka, G. A., Apparatus for monitoring the motion components of the spine, U.S. Patent Offices, Serial No. 09/336,896, 1990.

Marras, W. S., Fathallah, F. A., Miller, R. J., Davis, S. W. and Mirka, G. A. Accuracy of a three-dimensional lumbar motion monitor for recording dynamic trunk motion characteristics, International Journal of Industrial Ergonomics, 9, 75-87, 1992.

Marras and Davis, Spine loading during asymmetric lifting using one versus two hands, Ergonomics, 41(6), 817-834, 1998.

McGil, S. M., Searching for the safe biomechanical envelope for maintaining healthy tissue, Pre-ISSLS Workshop, The Contribution 
of Biomechanics to the Prevention and Treatment of Low Back Pain, University of Vermont, June 25, 1996.

Mirka, G. A. and Marras, W. S., A stochastic model of trunk muscle contraction during trunk bending, Spine, 18, 1396-1409, 1993.

Mital, A. and Ilango, M., Subjective estimates of one-handed carrying tasks, Applied Ergonomics, 14, 265-269, 1983.

Mital, A. and Kumar, S., Human muscle strength definitions, measurement, and usage: Part I - Guidelines for the practitioner, International Journal of Industrial Ergonomics, 22, 101-121, 1998a.

Mital, A. and Kumar, S., Human muscle strength definitions, measurement, and usage: Part II - The scientific basis(knowledge base) for the guide, International Journal of Industrial Ergonomics, 22, 123-144, $1998 \mathrm{~b}$.

Mo, Seung-Min., Kwag, Jongseon. and Jung, Myung-Chul., Literature Review on One-Handed Manual Material Handling, Journal of the Ergonomics Society of Korea, 29(5), 819-829, 2010.

NI-DAQ-DA2821, National Instruments Corporation, 11500N Mopac Expwy, Austin, Texas, U.S.A.

NIOSH(National Institute for Occupational Safety and Health), Work Practices Guide for Manual Liffing, Department of Health and Human Services Publication No. 81-122, 1981.

Waters, T. R., Putz-Anderson, V., Garg, A. and Fine, L. J., Revised NIOSH equation for the design and evaluation of manual lifting tasks, Ergonomics, 36(7), 749-776, 1993

\section{Author listings}

Hong-Ki Kim: hkkim@kyonggi.ac.kr

Highest degree: Ph. D., Department of Industrial Engineering, Texas Tech University

Position title: Professor, Department of Industrial and Management Engineering, Kyonggi University

Areas of interest: Biomechanics, Work Physiology, Psychophysics, MMH, WMSD, Product Development

Date Received : 2011-01-11

Date Revised :2011-07-19

Date Accepted : 2011-07-19 